\title{
A RELAÇÁo ENTRE CIÊNCIA NATURAL E COSMOLOGIA EM TOMÁS DE AQUINO
}

\author{
Evaniel Brás dos Santos ${ }^{1}$
}

Resumo: O presente estudo aborda a articulaçâo entre ciência natural e cosmologia em Tomás de Aquino. Para tanto, são investigadas as concepçôes da noção de cosmo, mediante a questão: o cosmo (mundo ou universo) pode ser o assunto central da ciência natural em Tomás? No intuito de refletir sobre essa questão, são apresentadas três concepçôes de cosmo. A primeira é a concepção da metafísica, na qual o cosmo é uma hierarquia de entes. A segunda, por sua vez, é a concepção da cosmografia segundo a qual o cosmo é a relaçấo de esferas intercaladas. A terceira, por fim, é a concepção da cosmologia que entende o cosmo como o conjunto dos corpos simples em perene locomoçáo natural.

Palavras-Chave: Ciência natural. Cosmo. Cosmologia. Cosmografia. Tomás de Aquino.

\section{A NoÇáo METAfísica de COSMO: A HIERARQUia DE ENTES}

Tomás de Aquino (1225-1274) segue um procedimento encontrado na tradução latina da Metaphysica de Aristóteles realizada por Moerbeke, qual seja, o não uso do termo latino cosmo. ${ }^{2}$ Com efeito, embora o termo grego

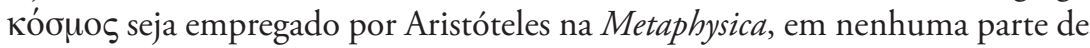
sua tradução Moerbeke emprega o termo latino cosmo para traduzir o termo grego mencionado. Em sua tradução, Moerbeke opta pelo termo mundus. ${ }^{3}$ É

${ }^{1}$ Pós-Doutorado Junior, CNPq, Universidade Federal da Bahia (UFBA), Salvador, BA - Brasil. (D) https://orcid.org/0000-0001-6662-3161 E-mail: evanielbras@gmail.com

${ }^{2}$ As obras de Tomás serão referenciadas do seguinte modo: ST (Summa Theologiae); SCG (Summa contra gentiles); QDP (Quaestiones Disputatae de Potentia Dei); In Sent. (Scriptum Super Libros Sententiarum Magistri Petri Lombardi); DSS (De substantiis separatis ad fratrem Raynaldum de Piperno); DEE (De Ente et Essentia); DAM (De aeternitate mundi); In Physica (In octo libros physicorum Aristotelis expositio); In DCM (In libros Aristotelis De caelo et mundo); In BDH (Expositio super librum Boethii De hebdomadibus); In GC (De generatione et corruptione); In SBT (Super Boetium De Trinitate).

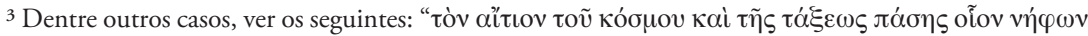

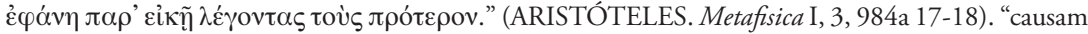
et mundi et ordinis totius ut excitans apparuit priores preter conuenientia dicentes." (ARISTOTELIS.

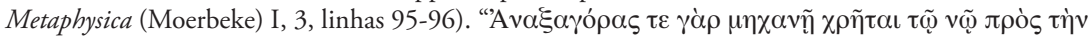

http://dx.doi.org/10.1590/0101-3173.2020v43n1.02.p17

This is an open-access article distributed under the terms of the Creative Commons Attribution License. 
importante ainda registrar que o termo latino cosmo não aparece nas traduçóes latinas da Physica e do De caelo editadas e publicadas pela Brepols. Isso se aplica não só às traduçôes de Moerbeke, mas também às traduçôes de Tiago de Veneza, a anônima, assim como a de Grosseteste. Nesse ínterim, é possível constatar que na Physica e no De caelo, Aristóteles, ao se referir ao conjunto formado pelos corpos celestes e pelos elementos, adota os termos tò ô $\lambda \mathrm{ov}$,

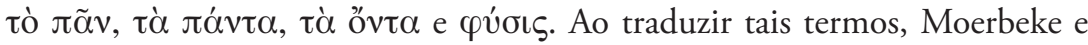
os demais tradutores citados, além do termo mundus, também empregam as seguintes opçóes: omnia, totus, universus, quae sunt e natura.

Ao que parece, a ausência do termo latino cosmo pode remontar a Agostinho ou às épocas anteriores. Numa passagem da De Civitate Dei, o bispo de Hipona escreve o termo em grego e emprega mundus como seu correspondente em latim: "Nas suas reflexóes preliminares sobre a teologia natural, o citado Varrão emite a sua opinião de que deus é a alma do mundo, que os gregos designam de kóouos, e de que este mesmo mundo é deus.”` Talvez o emprego do termo cosmo em contexto estranho à ciência natural (e à metafísica) seja a razão central pela qual os tradutores citados, assim como Tomás e Agostinho, não usam tal termo. ${ }^{5}$

Em todos os contextos da obra de Tomás, mundus e universus são necessariamente sinônimos e possuem, num primeiro momento, a mesma acepção do termo aristotélico Kóouos, incluído na ciência natural, a saber: o conjunto formado pelos corpos celestes e pelos elementos. Tomás começa a se diferenciar e a se distanciar do Estagirita quando, por um lado, aborda a natureza mesma do cosmo (ou mundo) e, por outro lado, entende o conjunto como corpo simples.

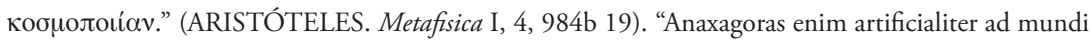

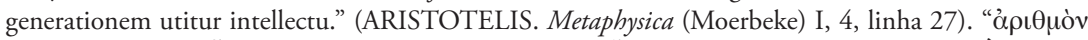

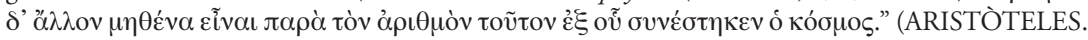
Metafísica I, 8, 989b 21-22). "numerum uero alium nullum esse preter numerum hunc ex quo constitit mundus?” (ARISTOTELIS. Metaphysica (Moerbeke) I, 8, linhas 108-109).

${ }^{4}$ De Civitate Dei, VII, 6. (Trad. João Dias Pereira, 1996-2000, modificada): "Dicit ergo idem Varro adhuc de naturali theologia praeloquens deum se arbitrari esse animam mundi, quem Graeci vocant

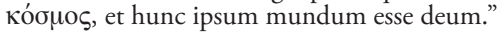

${ }^{5}$ Conforme Lewis e Short, o termo cosmoe foi empregado por Cícero (106-43a.C) em contexto político (cf. LEWIS; SHORT, 1958, p. 476). Ademais, os termos cosmus, cosmeta, cosmicos, cosmographia, cosmographus, cosmianus eram utilizados em Roma (cf. idem), como é atestado por Marco Valério Marcial (entre 38-41 d.C. - entre 102-104 d.C.) e Flávio Magno Aurélio Cassiodoro (490-575). Dentre as acepçóes dos termos, duas estão próximas das discussóes da ciência natural, quais sejam, a cosmographia entendida como "uma descrição do universo" (idem) e o cosmographus enquanto "alguém que descreve o mundo." (idem). 
Pelo viés da metafísica tomásica, o cosmo (ou mundo) é concebido como creatura. É, pois, uma cosmologia metafísica: "Parece que a universalidade das criaturas, denominada pelo nome de mundo, não começou, mas existe desde a eternidade." 'À luz da noção metafísica de criação, cujo sentido fundamental é conferir existência, o cosmo em si mesmo é constituído de entidades incorpóreas e corpóreas. A noção de incorporeidade, em seu sentido geral, possui três referenciais: a divinitas, a inteligência (anjo) e a alma intelectiva humana. Apenas o primeiro referencial não está incluído na natureza (ou constituição) do cosmo:

Ao segundo é preciso dizer que Deus não é alguma parte do universo, mas está totalmente além dele, pois possui em si mesmo, de um modo mais eminente, toda a perfeição do universo. $\mathrm{O}$ anjo, porém, é parte do universo. ${ }^{7}$

A explicação tomásica sobre a natureza do cosmo ocorre pelas noçôes de ordem e unidade, ou seja, a ordenação das partes constitui o todo, este que não inclui, é importante lembrar, a divinitas:

Os anjos, pois, são parte do universo: eles não constituem um universo em si mesmo, mas juntamente com a criatura corpórea constituem um mesmo universo. O que se mostra pela ordem de uma criatura em relação a outra, pois a ordem das coisas entre si é o bem do universo. Ademais, nenhuma parte é perfeita se separada do todo. ${ }^{8}$

Encontra-se subentendida, na passagem, uma noção de hierarquia dos entes, na qual os vivos, dentre os corpóreos, são os mais nobres. Nesse sentido, a locomoção natural, por ser o primeiro dos movimentos naturais, é o mais perfeito de todos, devendo ter como princípio ativo entes com determinados graus de ser (esse): a alma para os animais, ${ }^{9}$ os céus para os elementos e as

6 "Videtur quod universitas creaturarum, quae mundi nomine nuncupatur, non incoeperit, sed fuerit ab aeterno." (ST, Ia, q. 46, a. 1, Ad primum).

7 "Ad secundum dicendum quod Deus non est aliqua pars universi, sed est supra totum universum, praehabens in se eminentiori modo totam universi perfectionem. Angelus autem est pars universi." (ST, Ia, q. 61, a. 3, ad2).

8 "Angeli enim sunt quaedam pars universi, non enim constituunt per se unum universum, sed tam ipsi quam creatura corporea in constitutionem unius universi conveniunt. Quod apparet ex ordine unius creaturae ad aliam, ordo enim rerum ad invicem est bonum universi. Nulla autem pars perfecta est a suo toto separata." (ST, Ia, q. 61, a. 3, resp.).

${ }^{9}$ Cf. In Sent., II, d. 18, q. 1, a. 2, resp. 
inteligências para os céus. ${ }^{10}$ É devido à potencialidade que pertence à natureza da forma, ${ }^{11}$ seja da inteligência, seja dos corpóreos, que pela metafísica Tomás concebe o cosmo como hierarquia de entes. ${ }^{12}$ Quanto menos potencialidade houver na forma, mais o ente possui ser (esse) e, portanto, ato, e mais próximo está da divinitas. Por outro lado, quanto mais potencialidade, mais distante da divinitas, sendo que o limite da distância se encontra naquilo que, por si, é desprovido de forma, a saber, a matéria-prima. Portanto, quanto mais próximo da matéria-prima, mais potencialidade o ente possui, e isso de tal sorte que a forma, nesse caso, é totalmente material.

\section{Outro modo de tratar sobre a natureza do cosmo se dá pela articulação} entre permanência e transitoriedade:

No universo considera-se uma dupla natureza, a saber: a natureza da permanência sempiterna que se encontra, sobretudo, nas substâncias separadas, e a natureza gerável e corruptível que está nos corpos inferiores. Os corpos celestes, ao serem intermediários, participam de ambas as naturezas de algum modo, segundo os dois movimentos. Pois, o primeiro movimento, que é o diurno, é a causa da duração sempiterna nas coisas; e o segundo movimento, que é o círculo oblíquo do ocidente ao oriente, é a causa da geração, da corrupçáo e de outras transmutaçôes ou mudanças [...]. Assim, pois, o primeiro móvel, como é mais nobre e está mais próximo das substâncias separadas, na ordem da natureza, possui só o primeiro movimento, que pertence à natureza da uniformidade. Em contrapartida, os outros corpos celestes, na medida em que mais se afastam das substâncias imóveis, aproximando-se das substâncias geráveis e corruptíveis, participam de algo do outro movimento que pertence à natureza da não-uniformidade. ${ }^{13}$

\footnotetext{
${ }^{10}$ Cf. QDP, q. 5, a. 8, resp.

${ }^{11}$ Cf. SCG II, 50-54.

12 "Est ergo distinctio earum ad inuicem secundum gradum potentie et actus, ita quod intelligentia superior que magis propinqua est primo habet plus de actu et minus de potentia, et sic de allis. Et hoc completur in anima humana, que tenet ultimum gradum in substantiis intellectualibus." (DEE, c. $4,8-9 \$)$.

13 "quod in universo est duplicem naturam considerare: scilicet naturam sempiternae permanentiae, quae est maxime in substantiis separatis; et naturam generabilem et corruptibilem, quae est in inferioribus corporibus. Corpora autem caelestia, cum sint media, utraque aliqualiter participant, secundum duos motus. Nam primus motus, qui est diurnus, est causa sempiternae durationis in rebus: secundus autem motus, qui est in circulo obliquo ab occidente in orientem, est causa generationis et corruptionis et aliarum transmutationum [...]. Primum igitur mobile, tanquam nobilissimum et propinquissimum in ordine naturae substantiis separatis, habet solum primum motum, qui pertinet ad naturam uniformitatis. Alia vero corpora caelestia, inquantum magis recedunt a substantiis immobilibus, appropinquando substantiis generabilibus et corruptibilibus, aliquid participant de alio motu, qui pertinet ad naturam difformitatis." (In DCM II, 15, n. 8).
} 
Tomás afirma, portanto, que há uma dupla natureza no cosmo: a permanente e a transitória. A primeira é própria das inteligências (substantia separati), e a segunda, por sua vez, é própria dos elementos. Quanto aos corpos celestes, especificamente o céu sidério, este participa das duas naturezas, o que é assegurado mediante a afirmação do duplo movimento que realiza, o diurno (ou zodiacal) e o oblíquo, ou seja, o movimento próprio (motu proprio). ${ }^{14}$ Esses dois movimentos são afirmados com o propósito de mostrar o grau de nobreza de determinado corpo, o que ocorre pela concepção de que também o movimento pode ser dito mais e menos nobre de acordo com o fim, intrínseco e extrínseco. Se a referência é a nobreza do próprio corpo, então, o zodiacal é o movimento mais nobre, uma vez que, por ele, o corpo alcança seu fim intrínseco, a saber, assemelhar-se àquilo que lhe é superior tanto na posição quanto no ser. Em contrapartida, se a referência é outrem, o qual obviamente está abaixo do corpo em questão, tanto na posição quanto no ser, o movimento mais nobre é o próprio, pois, por este, o corpo em questáo é causa para outrem, alcançando assim seu fim extrínseco.

A nobreza do primeiro móvel (primus mobilis) é assegurada por Tomás pela noção de proximidade com relação às inteligências. Nesse contexto, Tomás admite que o primeiro móvel, porque se encontra no limite material do cosmo, se configura como o corpo móvel mais próximo das inteligências na ordem da natureza. Quanto aos planetas, após o primeiro móvel, numa escala decrescente, encontra-se Saturno, o planeta supremo, o qual Tomás contrapóe com o mais inferior dos planetas, a Lua. ${ }^{15}$ Ambos os planetas realizam o movimento próprio. Saturno realiza o movimento próprio do modo mais lento possível devido à intensidade na participação do movimento diurno do primeiro móvel e, consequentemente, da sempiternidade das inteligências. A Lua, por sua vez, realiza o movimento próprio do modo mais veloz possível, porque está muito distante do primeiro móvel e, consequentemente, das inteligências. Acima da Lua e abaixo de Saturno estáo Júpiter e os demais planetas, realizando os dois movimentos em seus períodos próprios e participando em menor grau do movimento diurno do primeiro móvel e na natureza das inteligências, quais sejam, Marte, Sol, Vênus e Mercúrio.

A articulção entre a dupla natureza encontrada no cosmo e o duplo movimento do céu sidério está fundamentada na noção metafísica de

\footnotetext{
${ }^{14}$ Sobre as noçôes de céu sidério, assim como de movimento diurno, oblíquo e próprio, ver a segunda seção deste estudo.

${ }^{15} \mathrm{Na}$ sequência da passagem de In DCM II, 15, n. 8.
} 
participação. Sobre a noção de participação, Tomás diz: "Participar é como tomar uma parte. E, assim, quando algo recebe de modo particular o que pertence a outro de modo universal, se diz que participa”. ${ }^{16}$ Nesse sentido, tomar parte no movimento de algo superior, ou seja, participar no movimento deste é ser de algum modo influenciado pelo seu movimento. Tomar parte na natureza de algo superior, isto é, participar na natureza dele é depender do superior enquanto motor. Se o motor é movente movido, então, o ente que lhe é inferior participa de seu movimento e de sua natureza. Se o motor é movente imóvel, logo, o ente que lhe é inferior, ao ser movido pelo motor, participa na natureza desse motor imóvel (inteligência).

\section{A NoÇáo de COSMO da CIÊNCIA NATURAL: O CONJUNTO DAS ESFERAS (A COSMOGRAFIA)}

Tomás náo emprega o termo latino cosmo e seus derivados, conforme já mencionado. Entretanto, é notória a presença de uma cosmografia na ciência natural tomásica, ou seja, uma descrição visual do cosmo. ${ }^{17}$ Aliás, é muito possível que Tomás tivesse acesso aos mapas nos quais se encontrava desenhada a figura do cosmo, quando redigia sobre a ciência natural. ${ }^{18}$ Embora sua confecção tenha ocorrido no século XVI, a figura do cosmo elaborada por Petrus Apianus (1495-1552), designada como Schema praemissae divisionis, ilustra a cosmografia do século XIII. ${ }^{19}$

$\mathrm{Na}$ figura do cosmo de Petrus Apianus há quinze esferas, desde a menor delas, a Terra, até a mais extensa, qual seja, a esfera do céu empíreo. Também a posição dos sete planetas coincide com a posição adotada por Tomás, a qual remonta a Ptolomeu e difere da concepção aristotélica. Os sete planetas, ademais, constituem uma parte do cosmo, situada na região superior, o céu

\footnotetext{
16 "Est autem participare quasi partem capere; et ideo quando aliquid particulariter recipit id quod ad alterum pertinet, universaliter dicitur participare aliud." (In BDH, 1. 2).

${ }^{17}$ A noção de cosmografia possui como um de seus expoentes Petrus Apianus: "Cosmographia (vt ex etymo vocabuli patet) est mundi, qui ex quatuor elementis, Terra, Aqua, Aere, e Igne, Sole quoq, Luna, e omnibus stellis constat, e quicquid caeli circumflexu tegitur, descriptio." (PETRI APIANI. Quid sit cosmographia, Fol. 1).

${ }^{18}$ Em três passagens do In DCM II Tomás emprega a expressão "caput et cauda", uma referência ao dragão (draco) desenhado pelos astrônomos. Cf. In DCM II, 13, n. 3; In DCM II, 17, n. 5; In DCM II, 21, n. 4 .

${ }^{19}$ Cf. PETRI APIANI. Schema praemissae divisionis, Fol. 3). A figura do mundo de Petrus Apianus pode ser facilmente vista na seguinte página da internet: https://digitalcollections.nypl.org/items/ adc4a100-90d8-0131-c0de-58d385a7b928\#item-data
} 
sidério. Além do céu sidério e do céu empíreo, também se encontra na região superior do cosmo o céu aquoso (ou cristalino). ${ }^{20}$

A introdução de dois céus, o empíreo e o aquoso, assim como a introdução da décima esfera, a esfera suprema, em sua concepção do cosmo, tornam tal concepção mais interessante e mais complexa e, ademais, tornam o cosmo de Tomás bem mais extenso do que aquele presente na concepçáo de Aristóteles. O próprio Tomás manifesta possuir plena consciência das novidades que a razão humana, representada pelos astrólogos (astrologus), ${ }^{21}$ como Ptolomeu e Hiparco, ${ }^{22}$ estabeleceu após Aristóteles:

Assim, este céu aquoso é a nona esfera, sobre a qual os astrólogos reduzem o primeiro movimento de ocidente a oriente, o movimento que é do orbe dos signos e que é comum a todas as estrelas; e ulteriormente [foi estabelecida] a décima esfera sobre a qual [os astrólogos] reduzem o movimento diurno, que é de oriente a ocidente. ${ }^{23}$

O movimento comum a todas as estrelas, cujo início se dá no ocidente celeste em direçấo ao oriente celeste, é compreendido por Tomás como o "primeiro" movimento de ocidente a oriente. Ele é dito "primeiro" porque, além de pertencer às estrelas, há um "segundo", o qual pertence à esfera de Saturno, assim como um "terceiro", pertencente à esfera de Júpiter, e assim sucessivamente até a esfera da Lua. Nesse sentido, todo o céu sidério possui o movimento de ocidente a oriente, também designado por Tomás de círculo oblíquo (circulo obliquo ${ }^{24}$, ou seja, o movimento zodiacal. ${ }^{25}$ É interessante notar que, diferentemente do movimento zodiacal, o qual é comum ao

20 "Ad quintum dicendum, quod per triplex caelum intelligitur, secundum Glossam, triplex genus visionis, vel etiam triplex hierarchia. Vel potest dici quod tertium dicitur Empyreum, ut tantum triplex caelum sumatur quod naturam caelestem habet, ut dictum est, scilicet Empyreum, chrystallinum, sidereum." (In Sent., II, d. 14, q. 1, a. 4, ad3.).

${ }^{21}$ No In DCM II, Tomás emprega a expressōes antiqui astrologi (In DCM II, 19, n. 6) e modernos astrologos, cf. In DCM II, 8, n. 2; In DCM II, 19, n. 6.

22 "Dicitur autem Anaximander primo invenisse rationem de magnitudinibus stellarum, et distantiis earum $\mathrm{ab}$ invicem et a terra; ordinem autem positionis planetarum dicuntur primi Pythagorici deprehendisse; quamvis cum maiori diligentia et perfectius sint haec considerata per Hipparchum et Ptolomaeum." (In DCM II, 15, n. 1. Grifo meu).

23 "Hoc autem caelum aqueum est nona sphaera, ad quam primo reducunt astrologi motum orbis signorum communem omnibus stellis, qui est de occidente in orientem; et iterum sphaeram decimam, ad quam reducunt motum diurnum, qui est de oriente in occidentem." (In Sent., II, d. 14, q. 1, a. 1, resp.).

${ }^{24}$ Cf. In DCM II, 15 , n. 8.

${ }^{25}$ Doravante, designarei o movimento comum de ocidente a oriente como "zodiacal". Ademais, empregarei o termo "diurno" apenas para a esfera suprema. 
céu sidério e ao céu aquoso, o movimento diurno da décima esfera não é propriamente comum a todo o céu, pois é o único que tem seu início no oriente celeste em direção ao ocidente celeste. No caso de a Terra ser tomada como referência, a décima esfera completa uma volta ao redor da Terra em vinte e quatro horas, saindo do oriente celeste e para lá retornando. ${ }^{26}$

Tomás admite três razóes pelas quais a décima esfera é entendida como o corpo móvel mais nobre (excellentia):

Sua excelência pode ser considerada a partir de três razóes: primeiro, porque é ordenada de modo mais imediato para o primeiro motor; segundo porque contém e carrega [gira] todas as demais esferas; terceiro, porque possui um movimento simplíssimo e velocíssimo. ${ }^{27}$

O primeiro motor (imóvel), se a referência diz respeito à totalidade do cosmo, só pode ser a divinitas, o criador. Nesse sentido, a décima esfera está ordenada a ser instrumento para o criador, sendo concebida simultaneamente como o primeiro móvel e como primeiro motor móvel. ${ }^{28}$ Ademais, a décima esfera possui apenas um único movimento, o diurno, de oriente a ocidente, razão pela qual ela possui um movimento simples. Por esse movimento simples, a décima esfera carrega consigo todos os demais corpos e esferas celestes. À exceção do céu aquoso, o qual é desprovido de astros, possuindo apenas o movimento zodiacal, o céu sidério não possui o movimento simples, mas o movimento zodiacal, do ocidente ao oriente, e o movimento próprio (proprio motu $)^{29}$, isto é, o movimento rotacional em torno do eixo de cada astro determinado que também ocorre de ocidente a oriente.

O duplo movimento realizado pelo céu sidério o torna "disforme nas partes".$^{30}$ Isso inclui as estrelas que Aristóteles considerava como "fixas", pois

\footnotetext{
26 "Supponimus enim, tanquam sensu apparens, quod suprema caeli circulatio sit simplex, idest non composita ex pluribus motibus, quia in ea nulla irregularitas apparet: et est velocissima, utpote quae in brevissimo tempore, scilicet spatio unius diei, circuit maximum circulum continentem totum." (In DCM II, 15, n. 2).

27 "Excellentia considerari potest ex tribus: primo quidem quia immediatius ordinatur ad primum motorem; secundo quia continet et revolvit omnes alias sphaeras; tertio autem quia habet motum simplicissimum et velocissimum.” (In DCM II, 19, n. 2).

${ }^{28} \mathrm{Na}$ figura do mundo de Petrus Apianus, Deus (Dei) é representado como primeiro motor imóvel e a décima esfera, por sua vez, como a primeira entidade a sofrer o movimento, isto é, o primeiro motor móvel (primu mobile).

${ }^{29}$ Cf. In DCM II, 15, n. 4.

30 "difforme in partibus" (In Sent., II, d. 14, q. 1, a. 4, resp.).
} 
entendia que elas não possuíam movimento próprio (proprio motu), ou seja, seriam imóveis per se e móveis pela esfera em rotação. ${ }^{31} \mathrm{O}$ movimento próprio das estrelas é uma descoberta que Tomás atribui a Ptolomeu: "Aristóteles, pois, admite que somente a esfera é movida e não as estrelas por si mesmas, porém, Ptolomeu admite que as estrelas possuem seu próprio movimento além do movimento da esfera." 32

A descoberta do movimento próprio das estrelas e sua admissão, como ocorre com Tomás, ${ }^{33}$ implica em alargar o cosmo grego, pois a esfera das estrelas fixas não pode ser a suprema esfera, que, para Aristóteles, era a última esfera (ultima sphaera). ${ }^{34}$ Assim, a concepção de cosmo do mestre do Liceu, pelo texto de Tomás, limita-se no céu sidério, abaixo do qual se encontra a região sublunar. A posição dos astros na concepção de céu do Estagirita, segundo Tomás, se dá do seguinte modo: $\left(1^{\circ}\right)$ estrelas fixas, $\left(2^{\circ}\right)$ Saturno, $\left(3^{\circ}\right)$ Júpiter, (4º) Marte, (5º) Vênus, (6º) Mercúrio, (7o) Sol, (8º) Lua. ${ }^{35}$

Numa escala descendente, aliás, perfeitamente representável na figura do cosmo de Petrus Apianus, Tomás assim entende a posição na região superior $\left(11^{\circ}\right)$ céu empíreo, sem astro e imóvel; $\left(10^{\circ}\right)$ décima esfera, a esfera suprema, sem astro, móvel e uniforme; $\left(9^{\circ}\right)$ céu aquoso ou nona esfera, sem astro, móvel e uniforme; $\left(8^{\circ}\right)$ esfera das estrelas; (7o) esfera de Saturno, o planeta

\footnotetext{
${ }^{31}$ Cf. In DCM II, 14, n. 10.

32 "Aristoteles enim vult tantum orbes moveri, et non stellas per se; sed Ptolomaeus vult stellas habere proprium motum, praeter motum orbis." (In Sent., II, d. 14, Expositio Textus).

33 "motus stellarum fixarum non erit omnino simplex, ut Aristoteles supponit, sed compositus ex duobus motibus." (In DCM II, 19, n. 3).

34 "Quod autem partes supremae sphaerae non moveantur irregulariter, ita scilicet quod una pars caeli quandoque citius quandoque tardius moveatur, ostendit supponendo [i.e., Aristóteles] quod sphaera stellarum fixarum sit suprema sphaera: nondum enim suo tempore deprehensum erat quod stellae fixae haberent proprium motum praeter motum diurnum; et ideo attribuit primum motum, scilicet diurnum, sphaerae stellarum fixarum, quasi proprium ei; cum tamen posteriores astrologi dicant quod sphaera stellarum fixarum habeat quendam proprium motum, supra quem ponunt aliam sphaeram, cui attribuunt primum motum." (In DCM II, 9, n. 1). Sobre a identificação aristotélica entre "suprema esfera" e "última esfera”, cf. In Physica IV, 7.

35 "Quorum primum est quod Aristoteles alium ordinem videtur assignare planetarum, quam astrologi nostri temporis. Primi enim astrologi posuerunt supremum planetam esse Saturnum, post quem posuerunt Iovem, tertio loco Martem, quarto solem, quinto Venerem, sexto Mercurium, septimo lunam. Astrologi autem qui fuerunt tempore Platonis et Aristotelis, mutaverunt hunc ordinem quantum ad solem, ponentes eum immediate supra lunam, sub Venere et Mercurio; quam positionem hic Aristoteles sequitur. Sed Ptolomaeus postea hunc ordinem planetarum correxit, ostendens verius esse quod antiqui dixerunt; quod etiam moderni astrologi sequuntur." (In DCM II, 17, n. 2).
} 
supremo; $\left(6^{\circ}\right)$ esfera de Júpiter; $\left(5^{\circ}\right)$ esfera de Marte; (40) esfera do Sol; $\left(3^{\circ}\right)$ esfera de Vênus; $\left(2^{\circ}\right)$ esfera de Mercúrio; $\left(1^{\circ}\right)$ esfera da Lua. ${ }^{36}$

\section{A NOÇÁO DE COSMO DA CIÊNCIA NATURAL: O CONJUNTO DOS CORPOS SIMPLES}

Além da concepção metafísica e da concepção da ciência natural no domínio da cosmografia, há ainda outra concepção da noção de cosmo, na ciência natural tomásica, uma concepção da cosmologia entendida aqui como cosmologia natural, para demarcar sua diferença da cosmologia metafísica. Enquanto, na metafísica, a noção de cosmo referencia diretamente a incorporeidade, não é uma tarefa simples decidir se a ciência natural tomásica referencia ou não a noção de incorporeidade, quando aborda a noção de cosmo. É possível que, no âmbito da causalidade, quanto à totalidade do $\operatorname{cosmo},{ }^{37} \mathrm{a}$ ciência natural referencie, direta ou indiretamente, a incorporeidade. Se isso ocorrer, sobretudo se for uma referência direta, ela se dará numa instância bastante aprofundada da ciência natural. Entretanto, nos primórdios de sua investigação, a ciência natural não referencia a noção de incorporeidade. Nesse contexto, Tomás se posiciona com clareza sobre os primórdios do tratamento da ciência natural sobre a noção de cosmo ou universo.

No In DCM, proémio, n. 3, bem como no In DCM I, 2, n. 1, Tomás emprega o caraterizador "corpóreo", para determinar a noção de universo com a expressão "universo corpóreo" (universum corporeum)..$^{38}$ É importante notar, ademais, que Aristóteles não tem nenhuma necessidade que o conduza a introduzir termos na Physica e no De caelo para caracterizar o cosmo, o universo (mundo) ou o todo, além das noçóes de unidade, perfeição e tridimensionalidade. Tomás sabe disso, pois é de modo deliberado que ele introduz o termo "corpóreo" para caracterizar o universo. A atitude de Tomás evidencia que, quando a ciência natural inicia sua investigação, já existe efetivamente uma cosmologia metafísica, a qual aborda a natureza do universo quanto à sua origem. Assim, é tarefa da ciência natural abordar a natureza do universo corpóreo no que concerne à posição e locomoção natural dos corpos simples que o constituem, os elementos

\footnotetext{
${ }^{36}$ Cf. In Sent., II, d. 14, q.1, aa. 1-5; ST, Ia, q. 68, aa. 1-4; In DCM II, 17.

${ }^{37} \mathrm{O}$ próprio Tomás emprega a expressão totum mundum: "Deus mundum facere potuit sine hominibus et animabus, vel tunc homines facere quando fecit, etiam si totum mundum fecisset ab aeterno; et sic non remanerent post corpora animae infinitae.” (DAM, p. 89, 4\$). Ver também: In Sent., III, d. 34, q. 3, a. 1, qc. 2, ad 2; SCG I, c. 27; SCG III, c. 120; SCG IV, c. 125; ST, IIae-IIa, q. 94, a. 1, resp.

${ }^{38}$ Tomás também emprega o expressāo "mundo corpóreo" (mundum corporeum), cf. ST, Ia, q. 61 a. 3, arg. 1; ST, Ia, q. 61 a. 3, ad1; In DCM I, 1, n. 2.
} 
e os corpos celestes. No intuito de apresentar a discussão sobre a abordagem da ciência natural sobre o cosmo como conjunto dos corpos simples, é preciso mencionar brevemente a noção de ciência natural em Tomás.

Tomás nomeia a mesma disciplina teórica de três maneiras, a saber: ciência natural (scientia naturalis), filosofia natural (philosophia naturalis) e física (physica). Enquanto ciência, a ciência natural necessita de um sujeito (subiectum) e do assunto central (materia) investigado por ela. O sujeito da ciência é aquilo que é tomado como evidente por ela, pois "nenhuma ciência prova a existência de seu sujeito." ${ }^{99}$ Ademais, o sujeito da ciência natural é o "ente móvel considerado de modo simples" ${ }^{40}$, ou seja: "o movido na medida em que é móvel." ${ }^{11}$ A referência ao ente móvel (ens mobile) visa a acenar para o aspecto de universalidade ou de matriz disciplinar da ciência natural, razão pela qual ela deve ser entendida como uma ciência geral e integral. A generalidade da ciência natural decorre do fato de ela ser a ciência teórica, depois da metafísica, que trata do ente, considerando-o do modo mais universal possível. Quanto à sua integralidade, esta diz respeito tanto ao fato de haver outras ciências naturais menos gerais, as quais tratam de determinados entes, quanto ao fato de essas ciências pressuporem a ciência natural, estando unidas a ela.

O assunto central da ciência natural é o corpo móvel (corpus mobile). ${ }^{42}$ É pela divisão desse assunto da ciência natural que são estabelecidas as ciências naturais. Tal divisão, com efeito, acompanharia a divisão dos livros de ciência natural feita pelo próprio Aristóteles, segundo Tomás:

Este é o livro da Física, que é designado também de Sobre o Físico ou Ensinamento Natural, porque foi transmitido aos ouvintes pelo modo de doutrinas, cujo sujeito é o ente móvel simplesmente. Não digo, entretanto, corpo móvel porque neste livro se prova que todo móvel é corpo e nenhuma ciência prova seu sujeito; e por essa razão, no início do livro do de Caelo, que vem depois deste, começa a investigaçáo sobre os corpos. Ademais, depois desse livro seguem os outros livros de ciência natural, nos quais se trata das espécies de móveis; por exemplo, no livro do de Caelo se trata do móvel segundo o movimento local, que é a primeira espécie de movimento; no livro de Generatione se trata do movimento para a forma

\footnotetext{
39 "nulla autem scientia probat suum subiectum." (In Physica, I, 1, n. 4). Noutra passagem, Tomás afirma: "Est igitur communis suppositio in scientia naturali quod motus habeat esse in rebus. Unde de hoc non est quaerendum in scientia naturali: sicut nec in aliqua scientia movetur quaestio de suppositionibus illius scientiae." (In Physica VIII, 1, n. 3).

40 “ens mobile simpliciter". (In Physica I, 1, n. 4).

41 "mobili inquantum est mobile". (In DCM I, prooemium, n. 3).

${ }^{42}$ Cf. In Physica, I, 1, n. 4. Ver também: In DCM I, 1.
} 
e dos primeiros móveis, a saber, dos elementos no que toca ao aspecto comum de suas transmutaçôes; quanto às transmutaçôes especiais se trata no livro do de Meteororum; dos móveis mistos inanimados se trata no livro do de Mineralibus; dos móveis animados se trata no livro do de Anima e nos livros que se seguem. ${ }^{43}$

O livro da Physica é um tratado geral da ciência natural, quer dizer, nele não há qualquer ciência natural determinada, mas tão somente a ciência natural em sua generalidade, isto é, consideraçóes gerais sobre o sujeito da ciência natural, o ente móvel. $\mathrm{O}$ assunto central da ciência natural, o corpo móvel, começa a ser determinado no De caelo. Aliás, além dessa afirmação sobre o De caelo, Tomás ainda assevera que, nesse livro, é investigado o móvel (mobile) submetido ao primeiro tipo de movimento, a locomoção natural.

A questão aqui surgida diz respeito a saber se o móvel submetido à locomoção natural (de mobili secundum motum localem) pertence à generalidade da ciência natural ou a alguma ciência natural determinada. Em outras palavras, é preciso saber se o De caelo é um livro da ciência natural enquanto matriz disciplinar ou não. Se a resposta for positiva, então, a noção de cosmo da ciência natural será entendida como "móvel segundo o movimento local", ou seja, o próprio cosmo encontra-se em locomoção natural, pois deve ser compreendido como o conjunto dos corpos (simples) em locomoção natural. Será, portanto, a locomoção natural do cosmo o caráter mais geral referente ao assunto central da ciência natural.

A questáo mencionada torna-se mais interessante pela leitura do proémio do In GC, mais precisamente pela seguinte passagem:

Como diz o Filósofo no de Anima III, as ciências se dividem de acordo com as coisas, pois todos os hábitos são distinguidos por seus objetos, dos quais recebem sua espécie. Ademais, as coisas que a Natural considera são o movimento e o móvel: o Filósofo diz na Physica II, que todo movente

\footnotetext{
43 "Hic autem est liber Physicorum, qui etiam dicitur de Physico sive Naturali Auditu, quia per modum doctrinae ad audientes traditus fuit: cuius subiectum est ens mobile simpliciter. Non dico autem corpus mobile, quia omne mobile esse corpus probatur in isto libro; nulla autem scientia probat suum subiectum: et ideo statim in principio libri de Caelo, qui sequitur ad istum, incipitur a notificatione corporis. Sequuntur autem ad hunc librum alii libri scientiae naturalis, in quibus tractatur de speciebus mobilium: puta in libro de Caelo de mobili secundum motum localem, qui est prima species motus; in libro autem de Generatione, de motu ad formam et primis mobilibus, scilicet elementis, quantum ad transmutationes eorum in communi; quantum vero ad speciales eorum transmutationes, in libro Meteororum; de mobilibus vero mixtis inanimatis, in libro de Mineralibus; de animatis vero, in libro de Anima et consequentibus ad ipsum." (In Physica I, 1, n. 4).
} 
movido pertence à especulação da física. E por essa razão, é necessário que, conforme a diferença dos movimentos e dos móveis, as partes da ciência natural sejam diferenciadas e ordenadas. Além disso, o primeiro dos movimentos é o movimento local, que é o mais perfeito dentre os outros e é comum a todos os corpos naturais, como é provado na Physica VIII. E por essa razão, após a consideração dos movimentos e dos móveis em comum, que foi tratada no livro da Physica, foi necessário, primeiramente, o tratamento sobre os corpos na medida em que são movidos no movimento local, empreendido no livro do De caelo, que é a segunda parte da ciência natural. ${ }^{44}$

A locomoção é investigada, segundo a passagem, na Physica e no De caelo. Na Physica, conforme Tomás, é provado que a locomoção é (i) o primeiro dos movimentos; (ii) é o mais perfeito dentre os movimentos; (iii) é comum a todos os corpos naturais. No De caelo, por seu turno, a locomoção natural é examinada quanto aos corpos locomovidos. A diferença entre as investigaçóes sobre a locomoção na Physica e no De caelo repousa no fato segundo o qual na Physica a investigação ocorre juntamente com o tratamento geral sobre os outros movimentos nas categorias da substância, da qualidade e da quantidade, enquanto, no De caelo, acontece apenas na categoria do lugar.

Duas outras afirmaçóes feitas no proémio do In GC interessam aqui. A primeira diz que a diferença nas partes da ciência natural (enquanto matriz disciplinar) decorre da divisão entre os movimentos e os móveis. Isso significa que, enquanto os movimentos e os móveis são tratados em comum (in communi), quanto à totalidade, a ciência natural ainda não se encontra dividida. A outra afirmação assinala que o De caelo é a segunda parte da ciência natural (est secunda pars scientiae naturalis). É necessário saber se a referência à "segunda parte" é alusiva ao estabelecimento de uma ciência natural determinada que ocorre com a divisão da ciência natural. Para tanto, é preciso abordar o proémio do In DCM.

\footnotetext{
44 "Sicut tradit Philosophus in III de Anima, scientiae secantur quemadmodum et res: nam omnes habitus distinguuntur per obiecta, ex quibus speciem habent. Res autem quas considerat Naturalis, sunt motus et mobile: dicit enim Philosophus in II Physic. quod quaecumque mota movent, sunt physicae speculationis. Et ideo oportet quod secundum differentiam motuum et mobilium, distinguantur et ordinentur partes scientiae naturalis. Primus autem motuum est motus localis, qui est perfectior ceteris, et communis omnibus corporibus naturalibus, ut probatur in VIII Physic. Et ideo post considerationem motuum et mobilium in communi, quae fuit tradita in libro Physicorum, primo oportuit quod tractaretur de corporibus secundum quod moventur motu locali, in libro de Caelo; quae est secunda pars scientiae naturalis." (In GC I, prooemium).
} 
No texto referido, Tomás apresenta uma discussão sobre o assunto central (subiectum) do De caelo, conforme as leituras de Alexandre de Afrodísias, Jâmblico, Siriano e Simplício. ${ }^{45}$ A discussão, conforme In DCM, proémio, nn. 4-5, gira em torno de quatro noçôes: universo (mundo/cosmo), corpo simples, corpo celeste, elemento, e diz respeito a saber qual dessas quatro noçóes constitui própria e primeiramente o assunto do De caelo. Com efeito, de acordo com a opção que se assume, a ciência natural é configurada de um ou de outro modo.

Jâmblico e Siriano são alocados na mesma posição, qual seja, o assunto central do De caelo é o corpo celeste (corpus caeleste), razão pela qual Aristóteles teria intitulado seu tratado de Sobre o céu. Quanto à presença, no De caelo, de outros assuntos relacionados a outros corpos distintos do corpo celeste, cada um possuiria uma justificativa. $O$ primeiro teria afirmado que a abordagem sobre os outros corpos se dá devido à causalidade celeste exercida sobre eles. O segundo, por sua vez, assinalaria que o conhecimento sobre os outros corpos é indispensável para o conhecimento sobre o corpo celeste, ou seja, que o conhecimento sobre o corpo celeste é derivado do conhecimento sobre os outros corpos. ${ }^{46}$ Tomás, entretanto, recusa a leitura de Jâmblico e Siriano, baseado na composição dos quatro livros do De caelo, isto é, apenas no segundo livro Aristóteles trata propriamente sobre os corpos celestes. Os demais livros ocupam-se de outros assuntos. ${ }^{47}$

Simplício conceberia que o assunto central do De caelo é o corpo simples. Eis o argumento de Simplício, segundo Tomás:

A intenção do Filósofo neste livro é determinar sobre os corpos simples na medida em que lhes convém a intençáo comum de corpo simples; e, dentre os corpos simples, o principal é o céu, do qual os outros dependem, razão pela qual todo o livro é denominado do céu. $\mathrm{E}$, como ele diz, não é um obstáculo que neste livro sejam determinadas algumas coisas pertencentes a todo o universo: porque as condiçóes destas convém ao universo na medida em que convém ao corpo celeste, a saber, ser finito e sempiterno, e assim por diante. ${ }^{48}$

\footnotetext{
${ }^{45}$ Como se sabe, Simplício também possui um In de Caelo, traduzido por Moerbeke para o latim, em 1271. Tomás teve acesso ao texto. Além da própria posição de Simplício, as posiçóes de Jâmblico, Siriano e Alexandre de Afrodísias são extraídas do prooemium do In de Caelo de Simplicio, cf. SIMPLICIUS. In de Caelo, prooemium, p. 1-3.

${ }^{46} \mathrm{Cf}$. In DCM, prooemium, n. 4, 2\$.

${ }^{47}$ Cf. Idem.

48 "intentio Philosophi in hoc libro est determinare de simplicibus corporibus, inquantum conveniunt in communi intentione simplicis corporis: et quia inter simplicia corpora principalius est caelum,
} 
A noção de intenção comum (communis intentio) referencia uma operação intelectual na qual o todo é concebido como anterior às partes que o constituem enquanto todo. No In DCM, proémio, n. 2, Tomás fornece dois exemplos matemáticos para esclarecer a noção de intenção (intentio): o círculo e o ângulo reto, sendo cada um entendido como um todo. É acidental que um e outro sejam divididos e postos na definição do semicírculo e do ângulo agudo respectivamente, pois, na intenção, ambos permanecem como todo. Nesse sentido, as noçóes de círculo e de ângulo reto antecedem logicamente às noçôes de semicírculo e de ângulo agudo.

No caso da noção de intenção comum aplicada às noções de corpo simples, de cosmo e de corpo celeste, a antecedência é uma antecedência lógica, a qual implica uma precedência real ou de natureza. Simplício, com efeito, não teria compreendido que o cosmo antecede por natureza às suas partes, sobretudo às principais, os corpos simples, e que, portanto, é necessário proceder da noção de cosmo em direçấo à noção de corpo simples e, desta, à noção de corpo celeste. O procedimento de Simplício, segundo Tomás, é justamente partir da noção de corpo simples em direção à noção de corpo celeste e, por fim, à noção de cosmo. Ademais, a intenção comum de corpo simples seria pensada por Simplício como o conjunto formado pelos corpos celestes e pelos elementos, sendo os corpos celestes os principais do conjunto, razão pela qual os principais atributos do cosmo lhe cabem, na medida em que primeiro são atribuídos aos corpos celestes.

A noção de cosmo da ciência natural presente no De caelo, na concepção de Simplício, conforme Tomás, é uma noção inflacionada por duas razôes. A primeira refere-se à inclusão das plantas e dos animais no cosmo descrito no De caelo. A segunda, por sua vez, diz respeito ao tratamento dos corpos simples não só na categoria do lugar, mas também nas categorias da substância, da

a quo alia dependent, ideo denominatur totus liber a caelo. Et, sicut dicit, non obstat quod in hoc libro determinantur quaedam quae pertinent ad totum universum: quia huiusmodi conditiones conveniunt universo inquantum conveniunt caelesti corpori, scilicet esse finitum et sempiternum, et alia huiusmodi." (In DCM, prooemium, n. 4, 3§). 


\title{
quantidade e da qualidade. ${ }^{49}$ Assim como fizera com a leitura de Jâmblico e Siriano, Tomás recusa partes da leitura de Simplício. ${ }^{50}$
}

\author{
Alexandre teria entendido que o assunto central do De caelo é o próprio \\ universo (cosmo):
}

Com efeito, Alexandre julgou que o assunto sobre o qual principalmente trata este livro é o universo mesmo. Nesse sentido, o céu se diz de três modos; algumas vezes diz respeito à última esfera; outras vezes a todo corpo movido circularmente; e algumas vezes ao universo mesmo; ele afirma que este livro é intitulado sobre o Céu, assim como poderia ser sobre o Universo ou sobre o Mundo. Nesta asserçáo, ele admite que o Filósofo neste livro determina certos assuntos pertencentes a todo o universo, por exemplo, que é finito, que é único, e assim por diante. ${ }^{51}$

A compreensão sobre a noção de céu não denotando diretamente o corpo celeste, mas o cosmo (ou mundo), a qual Tomás atribui a Alexandre, difere da compreensão de Simplício sobre a noção de céu, uma vez que, para este, o céu não denotaria a totalidade, enquanto, para aquele, o céu significa

\footnotetext{
${ }^{49}$ Tomás possuía aparato textual para entender a inflação mencionada. Embora Simplício não nomeie a discussão referente a Platão como "física", "ciência natural" ou "filosofia natural", é essa ciência que, para ele, Platáo estabelece no Timeu juntamente com uma metafísica. O próprio Simplício afirma, no proémio do In De caelo, que Platão, no Timeu, trata sobre os principia naturalium ("os princípios das coisas naturais"), os quais, para Simplício, são, dentre outros, a matéria, a forma, o tempo, o movimento e os céus: "deide quod non videtur de mundo docere in hiis, sicut Plato in Timeo principia naturalium, materiam, speciem et motum et tempus, et communem consistentiam mundi tradidit et singillatim de celestibus et de hiis que sub luna docuit et horum metheora quidem multipliciter tractat et que in terra metalla et plantas et animalia et usque ad consistentiam hominis et partium ipsius; hic autem de mundo toto dicta sunt paucissima et hec quecumque erant communia ipsi et celo, quod videlicet perpetuus et finitus magnitudine et unus et hec habens propter celum, quia hoc perpetuum et finitum et unum." (SIMPLÍCIO. In De caelo, prooemium, p. 3, 1. 72-73, p. 4, 1. 74-80.

50 "Si autem intentio principalis Philosophi esset determinare de universo, sive de mundo, oporteret quod Aristoteles considerationem suam extenderet ad omnes partes mundi, etiam usque ad plantas et animalia, sicut Plato in Timaeo. - Sed eadem ratione possumus arguere contra Simplicium: quia si in hoc libro principaliter intenderet de corporibus simplicibus, oporteret quod omnia quae pertinent ad corpora simplicia in hoc libro traderentur; nunc autem in hoc libro traduntur solum ea quae pertinent ad levitatem et gravitatem ipsorum, alia vero traduntur in libro de Generatione." (In DCM, prooemium, n. 4, 3\$).

51 "Alexander enim opinatus est quod subiectum de quo principaliter in hoc libro agitur, sit ipsum universum. Unde, cum caelum tripliciter dicatur, quandoque ipsa ultima sphaera, quandoque totum corpus quod circulariter movetur, quandoque autem ipsum universum, asserit hunc librum intitulari de caelo, quasi de universo vel de mundo: in cuius assertionem assumit quod philosophus in hoc libro determinat quaedam ad totum universum pertinentia, puta quod sit finitum, quod sit unum tantum, et alia huiusmodi." (In DCM, prooemium, n. 4, 1\$).
} 
exatamente a totalidade. É nesse contexto que é possível encontrar Tomás se referindo à Terra como alocada no meio do céu, ou seja, no centro do cosmo. ${ }^{52}$

É intrigante que Tomás não exponha a articulação feita por Alexandre entre as noçôes de cosmo e corpo simples, embora saiba de sua existência. ${ }^{53} \mathrm{Com}$ efeito, o argumento de Alexandre é apresentado sem referência à importante noção de corpo simples. Ao que parece, Tomás lê o argumento de Alexandre como um argumento totalmente focado na noção de cosmo como a razão central da confecção, não somente do primeiro livro do De caelo, mas também dos outros três. Nesse sentido, os termos "corpo celeste", "corpo simples" e "elemento", tratados no De caelo, devem manifestar a constituição primeira do cosmo em si mesmo, isto é, eles sempre são abordados no domínio da máxima generalidade possível, sempre da totalidade. Assim, tanto a noção de cosmo quanto as noçóes de corpo celeste, corpo simples e elemento presentes no De caelo não fazem referência à astronomia, à elementologia ou a qualquer outra ciência natural determinada: pertencem à ciência natural enquanto matriz disciplinar.

Tomás considera a posição de Alexandre a mais razoável: "o julgamento de Alexandre parece mais razoável, qual seja, o assunto deste livro é o universo mesmo, o qual é dito céu ou mundo." ${ }^{\prime 4} \mathrm{E}$, em seguida, complementa por conta própria:

E, neste livro, se determina sobre os corpos simples na medida em que são partes do universo. Ademais, o universo corpóreo é constituído por suas partes segundo a ordem da posição; e, por essa razão, neste livro só se determina sobre as partes do universo que primeiro e por si possuem posição no universo, quais sejam, os corpos simples. Donde, não se determina, neste livro, sobre os quatro elementos na medida em que são cálidos ou frios, ou algo semelhante; mas, somente na medida em que possuem gravidade e leveza, mediante os quais sua posição no universo é determinada. Porém, as outras partes do universo, por exemplo, as pedras, as plantas e os animais, náo possuem uma posição determinada por si mesmas, mas mediante os corpos simples, razáo pela qual não se trata disso neste livro. E, isso está de acordo com o que é usualmente dito entre os Latinos, que neste livro se trata do corpo móvel segundo a posição ou

\footnotetext{
52 "Sed quaedam conclusiones demonstrantur communiter a mathematico et naturali, ut utrum terra sit rotunda, et utrum sit in medio caeli." (In SBT III, 3, q. 5, a. 3, arg. 7.)

${ }^{53}$ Cf. SIMPLÍCIO. In De caelo, prooemium, p. 6.

54 "rationabilior videtur sententia Alexandri, quod subiectum huius libri sit ipsum universum, quod dicitur caelum vel mundus." (In DCM, prooemium, n. 5).
} 
segundo o lugar: certamente, este movimento é comum a todas as partes do universo. ${ }^{55}$

Corpo simples, conforme a passagem, é a entidade cósmica que por si mesma possui posição no cosmo. É pela categoria da posição que, embora sem os termos, se encontra na ciência natural tomásica uma articulação entre cosmografia e cosmologia natural. A articulação entre os dois estudos ocorre na medida em que, por um lado, as noçôes de esfera, elemento e planeta estáo na base da cosmografia e, por outro lado, a noçáo de corpo simples é investigada pela cosmologia. Pela cosmografia se entende que a esfera menos extensa é constituída pelo elemento terra e a esfera mais extensa é a última esfera. O cosmo, por conseguinte, em seu estado primeiro, é configurado como uma relação de esferas, na qual a esfera superior contém na concavidade de sua superfície a convexidade da superfície da esfera inferior. Pela cosmologia, por sua vez, em seu procedimento fundamental, a noção de corpo simples é concebida como denotando uma entidade não passível de percepção em estado puro e que, além disso, precede, por natureza, aos corpos mistos, como os minerais, as plantas e os animais, pois constitui o cosmo nele mesmo.

A importância da cosmografia para a cosmologia se dá, fundamentalmente, pelo caráter de universalidade e realismo da cosmologia. Em seu procedimento básico, a cosmologia emprega a noção de corpo simples sempre tendo como referência o todo, ou seja, o domínio do cosmo, não havendo, portanto, referência a um ou outro caso determinado, pois a determinação pertence ao âmbito da mistura e, por conseguinte, das ciências naturais particulares. É justamente nesse contexto que a cosmografia auxilia a cosmologia, pois a cosmografia configura o cosmo centrada naquilo que é passível de percepção e que é entendido como real. As teorias da cosmologia, por isso, precisam possuir sentido na descrição do cosmo da cosmografia, mesmo porque a cosmologia pretende explicar o real, embora este nem

\footnotetext{
55 "et quod de simplicibus corporibus determinatur in hoc libro, secundum quod sunt partes universi. Constituitur autem universum corporeum ex suis partibus secundum ordinem situs: et ideo de illis solum partibus universi determinatur in hoc libro, quae primo et per se habent situm in universo, scilicet de corporibus simplicibus. Unde et de quatuor elementis non determinatur in hoc libro secundum quod sunt calida vel frigida, vel aliquid huiusmodi; sed solum secundum gravitatem et levitatem, ex quibus determinatur eis situs in universo. Aliis autem partibus universi, puta lapidibus, plantis et animalibus, non determinatur situs secundum se, sed secundum simplicia corpora: et ideo de his non erat in hoc libro agendum. Et hoc consonat ei quod consuevit apud Latinos dici, quod in hoc libro agitur de corpore mobili ad situm, sive secundum locum: qui quidem motus communis est omnibus partibus universi." (In DCM, prooemium, n. 5).
} 
sempre denote aquilo que é percebido, como no caso do corpo simples em seu estado puro.

O emprego da noção de corpo na ciência natural possui sentido preciso:

Sobre os corpos é necessário atentar para três outras ordens: um modo segundo o qual todo o universo corpóreo é anterior as suas partes na consideração; outro modo na medida em que os corpos simples são anteriores aos mistos na consideração; o terceiro é este segundo o qual entre os corpos simples é necessário considerar antes o primeiro, qual seja, o corpo celeste pelo qual todos os outros são sustentados. E estes três [modos] são tratados neste livro que os Gregos intitulam sobre o Céu. Porque neste livro são transmitidas coisas relativas a todo o universo, como é manifesto no livro primeiro; coisas relativas ao corpo celeste, como é manifesto no segundo; coisas relativas a outros corpos simples, como é manifesto no terceiro e quarto. ${ }^{56}$

A consideração cosmológica sobre o corpo simples não evoca as categorias da substância, da quantidade e da qualidade. Ela evoca, além da categoria da posição, a categoria do lugar ou mais precisamente a abordagem sobre o aspecto comum às partes constituintes do cosmo: a locomoção natural. É, portanto, a locomoção natural do cosmo a máxima generalidade do assunto central admitido pela ciência natural. Assim, mesmo náo havendo o termo, há em Tomás uma cosmologia (natural) com sentido muito preciso: a investigação filosófica sobre a natureza e, sobretudo, a locomoção natural dos corpos simples entendidos como os constituintes essenciais do cosmo. Dentre os corpos simples se destacam, conforme a passagem citada, os corpos celestes: são necessários para a subsistência dos demais entes naturais (per quod omnia alia firmantur), nomeadamente, os elementos. É nesse contexto, ademais, que são estabelecidas a segunda e a terceira tese geral da cosmologia, isto é, (i) a locomoção natural circular dos corpos celestes e (ii) a locomoção natural centrípeta e centrífuga dos quatro elementos. As duas teses, aliás, são abordadas por Aristóteles, ao longo dos quatro livros do De caelo, segundo Tomás.

\footnotetext{
56 "In corporibus autem est attendere tres alios ordines: uno quidem modo secundum quod totum universum corporeum est prius in consideratione quam partes eius; alio modo secundum quod simplicia corpora prius considerantur quam mixta; tertio secundum quod inter simplicia corpora prius necesse est de priori considerare, scilicet de caelesti corpore, per quod omnia alia firmantur. Et haec tria in hoc libro aguntur, qui apud Graecos intitulatur de caelo. Traduntur enim in hoc libro quaedam pertinentia ad totum universum, sicut patet in primo libro; quaedam pertinentia ad corpus caeleste, sicut patet in secundo; quaedam pertinentia ad alia simplicia corpora, sicut patet in tertio et quarto." (In DCM, prooemium, n. 3).
} 


\section{Consideraçótes Finais}

Há uma noção, na abordagem aristotélica das teses mencionadas, a qual torna a ciência natural e a cosmologia bastante complexas, sobretudo quando o Estagirita vincula as teses, qual seja: a necessidade. Dito de outro modo, para Aristóteles, conforme Tomás, só há locomoção natural centrípeta e centrífuga dos elementos, na medida em que o conjunto formado pelos corpos celestes, o céu, realiza constantemente sua locomoção natural circular. A necessidade celeste, além disso, não diz respeito apenas aos elementos, mas também se refere à própria natureza do cosmo, ou seja, a unidade, a integridade, a perfeição e o ordenamento do cosmo reclamam pelo corpo celeste.

Tomás, ao que parece, prossegue além de Aristóteles na busca pelas razóes da necessidade celeste, embora coloque as palavras na boca do Estagirita, sobretudo quando postula o princípio escolástico segundo o qual "a obra da natureza é a obra da inteligência (opus naturae est opus intelligentiae)." 57 Ora, se o corpo celeste é natural e obra da natureza, então também ele está submetido a uma causa superior inteligente. Isso significa que compete à causa da necessidade estabelecer o modo da relação entre os constituintes do cosmo, as inteligências, os elementos e os corpos celestes.

O que justifica a necessidade celeste é a causa superior cujo atributo, Tomás aponta, é a incorporeidade (nec corporalis). ${ }^{58}$ É muito importante essa constatação, pois Tomás afirma simultaneamente que a locomoção celeste é necessária e que possui uma causa incorpórea de sua necessidade. Assim, o corpo celeste é natural, assim como sua locomoçáo, embora o modo como ocorre a relação com os demais constituintes do cosmo advenha diretamente da causa transcendente, uma tese que torna a ciência natural e a cosmologia, em Tomás, bem mais complexas do que em Aristóteles.

\footnotetext{
57 "Sed in quibusdam ista cognitio non est conjuncta tendenti in finem; unde oportet quod dirigatur per aliquod prius agens, sicut sagitta tendit in determinatum locum per determinationem sagittantis; et ita est in omnibus quae agunt per necessitatem naturae; quia horum operatio est determinata per intellectum aliquem instituentem naturam; unde, philosophus dicit, quod opus naturae est opus intelligentiae." (In Sent., I, d. 35, q. 1, a. 1, resp.).
}

${ }^{58}$ Cf. ST, II-II, q. 95, a. 5, resp. 
SANTOS, E. B. The relationship between natural and cosmology in Thomas Aquinas. Trans/form/ação, Marília, v. 43, n. 1, p. 17-38, Jan./Mar., 2020.

\begin{abstract}
The present study aims to articulate natural science and cosmology in Thomas Aquinas. Accordingly, I want to investigate the conceptions of cosmos by the following question: can the cosmos (world or universe) be the central topic of natural science in Aquinas? I present three conceptions of cosmos in order to reflect upon this question. The first is the metaphysical one in which the cosmos is a hierarchy of entities. The second is related to cosmography according to which the cosmos is a relation of intercalated spheres. The third, finally, is the cosmological conception that understands the cosmos as the set of simple bodies in perennial natural locomotion.
\end{abstract}

KeY-Words: Natural science. Cosmos. Cosmology. Cosmography. Thomas Aquinas.

\title{
REFERÊNCIAS
}

AGOSTINHO. A cidade de Deus. Tradução de João Dias Pereira. Lisboa: Fundação Calouste Gulbenkian. 1996-2000.

ARISTOTELES LATINUS VII 1. Physica (translatio Iacobus Veneticus). New York: Brill, 1990.

ARISTOTELES LATINUS VII 2. Physica (translatio Vaticana). New York: Brill, 1990.

ARISTOTELES LATINUS (translatio Moerbeke). De caelo et mundo; Metaphysica. In: BRAMS, J.; TOMBEUR, P. (coaut. de). Aristoteles Latinus database. Turnhout: Brepols, 2003.

ARISTOTELES LATINUS. De caelo et mundo: liber II (translatio Robertus Grosseteste). In: BRAMS, J.; TOMBEUR, P. (coaut. de). Aristoteles Latinus database. Turnhout: Brepols, 2003.

ARISTOTLE. Physics. W. D. Ross (ed.). Oxford: Clarendon Press, 1936 .

ARISTOTLE. De caelo. D. J. Allan (ed.). Oxford: Oxford University Press, 1936b.

ARISTOTLE. Metaphysics. W. D. Ross (ed.). Oxford: Clarendon Press, 1975.

ARISTOTELES. Physica (trad. Moerbeke). In: In octo libros physicorum Aristotelis expositio. Commissio Leonina. Roma: Typographia Polyglotta, 1884. v. II

ARISTOTELES. Physica (trad. Miguel Escoto). In: Aristotelis opera cum Averrois commentariis. Venetiis apud Junctas 1562-1574, repr. Frankfurt: Minerva, 1962. v. IV.

ARISTOTELES. Super libro de celo et mundo Aristotelis (trad. Miguel Escoto). In: Commentaria Magna in Aristotelem De celo et mundo. Venetiis apud Junctas 1562-1574, repr. Frankfurt: Minerva, 1962. v. V. 
AUGUSTINUS. De civitate Dei. Ed. B. Dombart et A. Kalb. CCSL, Scholars' Version, Turnhout: Brepols, 2003. p. 47-48.

LEWIS, C. T.; SHORT, C. Oxford Latin Dictionary. Oxford: Oxford Clarendon Press, 1958.

PETRI APIANI. Quid sit cosmografia. In: Cosmographia Petri Apiani, per Gemmam Frisium apud Louanienses medicum... Parisiis, væneunt apud Viuantium Gaultherot, via Iacobea: sub intersignio D. Martini, 1553a.

PETRI APIANI. Schema praemissae divisionis. In: Cosmographia Petri Apiani, per Gemmam Frisium apud Louanienses medicum... Parisiis, væneunt apud Viuantium Gaultherot, via Iacobea: sub intersignio D. Martini, 1553b.

THOMAE DE AQUINO. In octo libros physicorum Aristotelis expositio. Opera omnia iussu impressaque Leonis XIII P. M. Roma: Typographia Polyglotta, 1884. v. II.

THOMAE DE AQUINO. In libros Aristotelis De caelo et mundo. Commissio Leonina. Roma: Typographia Polyglotta, 1886a. v. III.

THOMAE DE AQUINO. De generatione et corruptione. Commissio Leonina. Roma: Typographia Polyglotta, 1886b. v. III.

THOMAE DE AQUINO. Summae Theologiae. Commissio Leonina. Roma: Typographia Polyglotta, 1888-1906. v. IV-XII.

THOMAE DE AQUINO. Summa contra gentiles. Commissio Leonina. Roma: Typis Riccardi Garroni, 1918-1930. v. XIII-XV.

THOMAE DE AQUINO. Quaestiones Disputatae de Potentia Dei. Ed. P. Mandonnet. Paris: P. Lethielleux, 1925. v. II.

THOMAE DE AQUINO. Scriptum Super Libros Sententiarum Magistri Petri Lombardi. Ed. P. Mandonnet. Paris: P. Lethielleux, 1929. v. 1-2.

THOMAE DE AQUINO. Summa contra gentiles. Roma: Marietti, 1961-1967.

THOMAE DE AQUINO. De substantiis separatis ad fratrem Raynaldum de Piperno. Commissio Leonina. Roma: Ad Sanctae Sabinae, 1969. v. XL.

THOMAE DE AQUINO. De aeternitate mundi. Commissio Leonina. Roma: Editori di San Tommaso, 1976. v. XLIII

THOMAE DE AQUINO. Super Boetium De Trinitate. Expositio libri Boetii De ebdomadibus. Commissio Leonina. Paris: Éditions du Cerf, 1992. v. L.

Recebido: 24/01/2017

Aceito: 30/06/2019 


\title{
Comentário
}

\section{EVANIEL BRÁs: A RELAÇÃo ENTRE CIÊNCIA NATURAL E COSMOlogia EM ToMÁs de AQuino}

\author{
Jakob Hans Josef Schneider ${ }^{60}$
}

O tema do artigo aqui comentado atinge uma das perspectivas mais importantes na Idade Média, mas que é, ao mesmo tempo, apenas de um interesse histórico. ${ }^{61}$ Trata-se do que se chama, em alemão, Weltbild (imagem do mundo) ou Weltanschauung (imaginação, ou seja, intuição do mundo), decisivamente e irreversivelmente revolucionada pela descoberta do telescópio que Galilei (Siderius Nuncius, Venecia, 1610) dirigiu à lua e apagou com essa ação a divisão aristotélica da toda realidade entre uma realidade acima da esfera da lua e abaixo da esfera da lua. A lua tornou-se a mesma sujeira como a da terra; melhor: dependendo da perspectiva, a terra virou uma das estrelas, entre outras. Pelo menos o telescópio mostrou que, no universo todo, dominam as mesmas leis naturais.

Para mostrar o mérito do artigo de Brás, indicarei quatro pontos que podem esclarecer o fundo intelectual de Tomás de Aquino, que não é um expert em astronomia ou cosmologia. Ele depende, a esse respeito, das informaçóes, sobretudo das traduçóes das obras de Aristóteles, dos comentadores dele e de outras fontes, como de Ptolomeu, por exemplo, e da filosofia árabe, a exemplo de Avicena.

Um primeiro ponto é o seguinte: tanto na Antiguidade quanto na Idade Média, a divisão da realidade entre duas realidades bem diferentes é

\footnotetext{
${ }^{60}$ Docente na Universidade Federal de Uberlândia. E-mail: jakob.schneider@ufu.br

${ }^{61}$ Litt (1963) trata do assunto de modo magistral e completo.
}

http://dx.doi.org/10.1590/0101-3173.2020v43n1.03.p39 
deveras significativa, aliás, tanto quanto na filosofia árabe (Avicena), judaica (Moises Maimônides) e cristã (Tomás de Aquino). Tal dualidade domina a divisão das ciências filosóficas também, como no sistema da formação escolar das septem artes liberales, no qual a astronomia faz parte do quadrivium junto com a aritmética, geometria e música. São scientiae reales, ao passo que o trivium representa as scientiae sermocinales, ciências da linguagem. As scientiae reales, ou seja, o quadrivium, são ciências matemáticas. Aliás, podemos definir a cosmologia como uma "geometria celeste", pois mede as proporçóes entre os movimentos celestes. No século XIII, esse sistema da formação escolar mudou com a De divisione philosophiae de Dominicus Gundissalinus e com a tradução do Al-Farabi De scientiis (SCHNEIDER , 2011, p. 41-51) e, sobretudo, com a constituição das universidades medievais. Um resumo se encontra na Margarita philosophica, de Gregorius Reisch (Ex Heidelberga iij KP Januarias. 1496, Venecia, 1502, fol. 3). Gregorius divide a philosophia em a philosophia theorica siue speculativa e a philosophia pratica; a philosophia speculativa, ademais, em a philosophia rationalis e realis. As ciências matemáticas, o quadrivium, são situadas na parte da philosophia realis, como também a metaphysica. Nesse sentido, é importante mencionar que a metafísica pertence às ciências reais, como Tomás de Aquino a situa sempre nos seus proêmios aos seus comentários dos libri naturales de Aristóteles. Segundo Tomás, a metafísica é, em primeiro lugar, uma análise da substância e, nesse ponto, trata-se, então, da questão se temos que contar com substantiae separatae enquanto princípios dos movimentos celestes.

Nessa Margarita philosophica se encontra também a sistematização antiga das ciências naturais, ou seja, dos libri naturales de Aristóteles, na seguinte ordem: segundo Tomás, precisamos começar através de um princípio científico, a saber, da aplicação do universal ao particular, com a (1) Física (

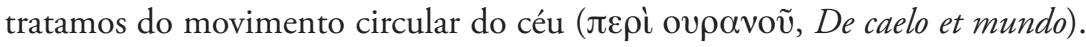
(3) Depois, do movimento substancial (De generatione et corruptione), (4) do movimento linear (Meteora) e (5) De mineralibus (um escrito pseudoaristotélico) até o (6) movimento da alma (De anima), o Sextus Liber de Naturalibus, como Avicena o nomeia. Isso quer dizer até os princípios do ser que são, em primeiro lugar, princípios inteligíveis, ou seja, inteligências e, em segundo lugar, causas segundas; e nesse contexto, até o primeiro princípio das coisas naturais que deveria ser um intelecto: o primeiro motor imóvel, pois um movimento circular simboliza um movimento intelectual, tanto na alma intelectiva do ser humano (reflexão) quanto nas "almas motrizes celestes" que 
se chamam inteligências ou intelectos separados ou substâncias separadas ou anjos. Mas essa pesquisa do intelecto (voṽ $\zeta$ ) não é um assunto das ciências naturais, mas da metafísica, pois o intelecto é imaterial e não pode ser, por causa disso, um objeto da filosofia natural.

Dado que o movimento circular é um símbolo de um movimento espiritual, preciso me referir a um trecho da Metafísica (XII. 7. 1072 b 18-31) de Aristóteles, onde ele caracteriza o primeiro motor imóvel que ele chama

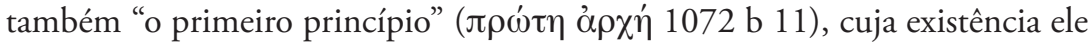
já mostrara no VIII. Livro da sua Física (cap. 7-9) de seguinte modo:

Ora, o pensar (vółбı५) em si mesmo ocupa-se com aquilo que é em si mesmo o melhor, e o pensar no mais elevado sentido com aquilo que é no mais elevado sentido o melhor. E o pensamento pensa a si mesmo através da participaçáo no objeto do pensamento. De fato, torna-se um objeto do

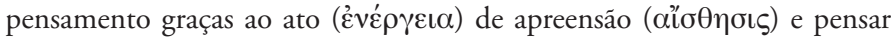

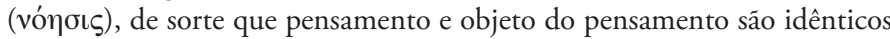
( (oเov́tov), porque aquilo que é receptivo do objeto do pensamento, isto é, a substância (oướa), é pensada. E ele funciona em ato ao possuir esse objeto. Consequentemente, é o ato e não a potência o elemento divino que parece que o pensamento encerra, e o ato da especulação $\left(\theta \varepsilon \omega \operatorname{cí}^{\alpha}\right)$

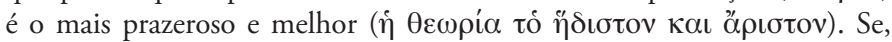
entáo, Deus está naquele bom estado no qual as vezes estamos, isso suscita nosso maravilhamento ( $\theta \alpha v \mu \alpha \sigma \tau o ́ v)$, e se num melhor ainda, experimentamos um maravilhamento ainda maior. E Deus está num estado melhor. Ademais, a vida ( $\zeta \omega \eta ̛$ ) também pertence a Deus, já que o ato de

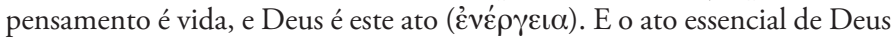

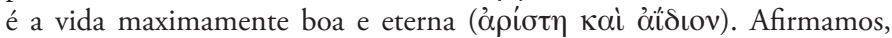
portanto, que Deus é um ser vivo, eterno, maximamente bom, e portanto a vida e uma contínua existência eterna dizem respeito a Deus, pois isso é o que Deus é. (ARISTÓTELES, 2014).

A tese da identidade do pensamento e do objeto de pensar leva às

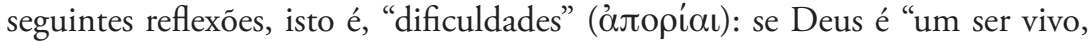
eterno, maximamente bom" e está pensando sempre em ato; e se pensar significa sempre pensar algo; o que é, então, que Deus pensa? Se ele, enquanto

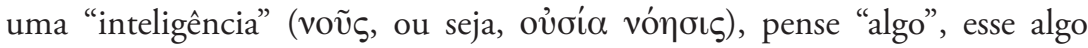
deveria, enquanto um pensamento possível, limitar sua existência eterna e infinita de pensar, que contradiz sua essência de estar sempre em ato de pensar, a saber, uma contínua existência eterna, ou seja, uma "substância mais

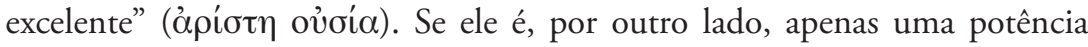

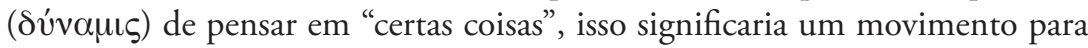


o "pior", que contradiz o fato de que ele pensa sempre num sentido mais elevado, o melhor. Mas a "vida maximamente boa e eterna" é sua própria vida. "A conclusão é que a inteligência pensa a si mesma, se é isto o melhor - e o seu

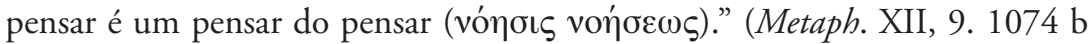
15-34). Aqui se encontra a identidade do pensar e do pensado e, então, num sentido mais alto, a autoidentidade e a autopresença do espírito. Uma teoria do intelecto e seus vários usos linguísticos é necessária, pois os movimentos celestes são relacionados, acerca dos princípios de seus movimentos, com os princípios inteligíveis que se chamam intelligentias.

Quanto a uma teoria do intelecto, preciso acrescentar um segundo

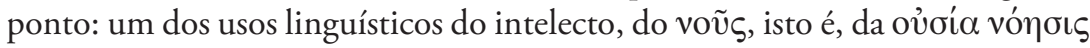
surge de uma questão do Livro XII, cap. 8. 1073 a 15-1074 b 14 da Metafísica: quantos "princípios motrizes imóveis" precisamos assumir fora do primeiro

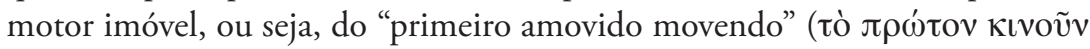

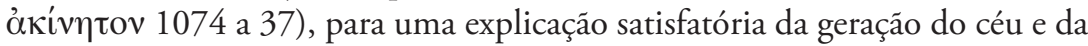
natureza? Aristóteles deixa essa questão em aberto. Apenas Avicena preencherá essa falta de explicação.

É bem claro que só há um único céu (oủpavós, (1074 a 31)). No entanto, com quantas substâncias inteligíveis, que a tradiçãa aristotélica chama também intelligentiae (os cristãos "anjos"), devemos contar, isso é um assunto da astronomia, ou da "geometria celeste". Na realidade, é um assunto da metafísica. Trata-se do primeiro princípio do ser, de um intelecto puro estando sempre em ato de pensar, quer dizer, da relação entre a eternidade divina e a temporalidade do mundo, ou seja, da concepção filosófica da generatio do mundo ou da concepção teológica da creatio ex nihilo do mundo. No XII. Livro das Confessiones, Agostinho tenta dar uma resposta ao problema da eternidade do mundo, segundo a qual temos a ver com uma separaçáo estrita entre eternidade divina e temporalidade do mundo. A esse respeito, e através da distinção entre aeternitas (sem início no tempo e sem fim) e sempiternitas (início no tempo e duração continua e infinita), Tomás se posiciona bem claro, no seu De aeternitate mundi: as duas proposiçôes, "o mundo é criado", a saber, tem um início no tempo, e "o mundo é eterno" são compatíveis e não se contradizem. Nisso concorda a posição de Moises Maimônides e, como mostrei (SCHNEIDER, 1999, p. 121-141), também a de Averróis.

Ademais, é bem claro, o primeiro motor imóvel é eterno. Logo, o primeiro movimento gerado é também eterno. $\mathrm{O}$ assunto em questão é: como a pluralidade dos "mundos" dentro desse único céu pode ser gerada, no caso 
em que ex uno non fit nisi unum (a partir do Uno só se torna um Uno) é um princípio válido. Como podemos explicar, entáo, o fato da pluralidade das coisas, em face da unidade do primeiro princípio? Avicena oferece uma resposta, mais influente na Idade Média, na sua Metaphysica sive scientia divina. Ela é bem conhecida até pelo menos Girolamo Savonarola. ${ }^{62}$

Um terceiro ponto, por conseguinte: a Idade Média conhece outras respostas à questão de como o mundo foi gerado, ou seja, foi criado: o Liber de causis, surgido da escola de Al-Kindi, o manual da metafísica medieval, a Theologia Aristotelis, também nascida na escola de Al-Kindi e, sobretudo, o pequeno tratado De intellectu et intellecto, de Al-Kindi com o qual ele iniciou um genre littéraire específico na Idade Média. Em seguida, aparecem o De intellectu et intellecto, de Al-Farabi (cf. SCHNEIDER, 2015, p. 224-246), De intelligentiis, de Avicena, e o comentário de Averróis ao De anima de Aristóteles. A partir do tratado de Al-Kindi sobre o intelecto, surgem muitos tratados e comentários na Idade Média latina: os anônimos De potentiae animae, Alberto Magno, De intellectu et intelligibili, Sigero de Brabant, De anima, entre outros, sempre com respeito ao capítulo 5 do III. De anima, de Aristóteles.

Os capítulos 4, 5 e 6 do III. Livro do De anima são de grande importância para a filosofia medieval. Brás cita, com toda razão, esse III. Livro do De anima. No capítulo 5 (430 a 10-19), Aristóteles repete, a propósito do

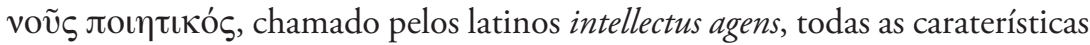
do XII. Livro da sua Metafísica capítulo 7 . Ele é: ${ }^{63}$

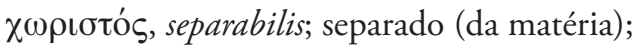

ả $\alpha \theta \dot{\eta} \varsigma$, non mistus passioneque vacat; impassível;

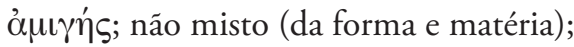

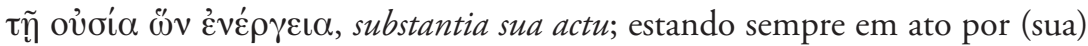
natureza;

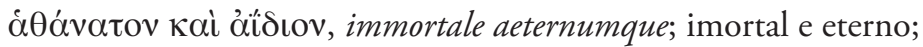

${ }^{62}$ Cf. SAVONAROLA (2012, p. 241): "quia ab uno non procedit nisi unum in quodam una, ut dicit Avicenna, qui hanc opinionem sequitur, tum quia ab una causa perfectissima non potest procedere nisi unus effectus perfectissimus [...]".

${ }^{63}$ Por causa dos termos latinos, cf. ARISTOTELES, Opera Omnia, Graece et Latine, cum Indice Nominum et Rerum. Paris: Ambrosio Firmin Didot, Instituti Imperialis Franciae Thypographo, Via Jacob 56, 1848-1854, v. III, p. 468. Ver também: Aristoteles Latine. Interpretibus variis edidit Academia Regia Borussica. Berlin, 1831, apud REIMERUM, Georgium. Nachdruck herausgegeben und eingeleitet von Eckhard Kessler. Humanistische Bibliothek. Texte und Abhandlungen, begründet von Ernesto Grassi, Reihe II, Texte Band 30. München. Wilhelm Fink, 1995; De anima, tradução de Johannes Argyropulos (1415-1487), p. 223. 


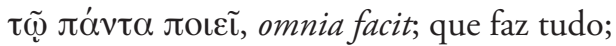

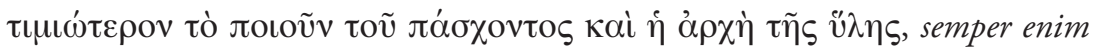
id quod agit, praestabilius est eo, quod patitur, et principium materia; sempre é aquela coisa mais nobre que age do que aquela que sofre, e o princípio do que a matéria.

Avicena, por exemplo, situa esse intelecto agente na esfera da lua, que, cheia das formas inteligíveis, dá para os homens as espécies inteligíveis, a saber, o conhecido. Essa tese é, para Tomás, inaceitável. No entanto, o que Tomás aceita é a reinterpretação das ideias platônicas enquanto pensamentos de um intelecto (intellectus agens) e não substâncias separadas e criadoras e, na base disso (Avicena), as ideias tornam-se razôes eternas, isto é, ideias divinas (Santo Agostinho). Trata-se, aqui, daquilo que Gilson (1926, p. 5-127) chama "l'augustinisme avicennisant" (veja Summa theologiae I, 84, 4 e 5).

$\mathrm{Na}$ realidade, a tradição filosófica da filosofia árabe é um conjunto da cosmologia e metafísica (DAVIDSON, 1992) para uma explicação estritamente filosófica da geração do mundo, na base de um aristotelismo neoplatonizante, na base da Plotiniana arábica. Tomás, por seu turno, explica a geração do mundo no seu comentário do Liber de causis, na base da Elementatio theologica, de Proclo, que ele conheceu através da tradução de Guilherme de Moerbeke e corrigiu, por meio do Dionísio Areopagita. O que interessa a Tomás, na cosmologia, é que o mundo não surgiu por acaso. Ele é criado por uma inteligência divina; e isso, junto com Aristóteles, na sua Física (II, 6. 198a10-14): "antes de tudo o pensamento e a natureza são a causa de todo o ser.” (SCHNEIDER, 2013, p. 395-410).

Um quarto ponto é o seguinte: conhecemos, na Idade Média, uma tradiçáo que Clemens Baeumker chama, no seu Witelo (Vitelo), ${ }^{64}$ "Lichtmetaphysik" (metafísica da luz), ou seja, "Perspektivwissenschaft"

${ }^{64}$ Cf. BAEUMKER, C. Witelo. Ein Philosoph und Naturforscher des XIII. Jahrhunderts (Beiträge zur Geschichte der Philosophie und Theologie des Mittelalters, 3/2). Münster: Aschendorff, 1908, Repr. 1991. Witelonis Perspectivae liber primus: Book I of Witelo's "Perspectiva": An English Translation with Introduction and Commentary and Latin Edition of the Mathematical Book of Witelo's "Perspectiva", ed. and transl. S. Unguru, Studia Copernicana, Nr. 15, Wroclaw 1977; Witelonis Perspectivae liber quintus: Book V of Witelo's Perspectiva: An English Translation with Introduction and Commentary and Latin Edition of the First Catoptrical Book of Witelo's Perspectiva, ed. and transl. und A. Mark Smith, Studia Copernicana, Nr. 23, Wroclaw 1983. 
(ciência da perspectiva), surgida da ótica, a nova ciência na Idade Média latina do século XIII, vindo do árabe, a saber, do Al-Kindi. ${ }^{65}$

A esse respeito, Brás menciona Roberto Grosseteste (2012). Posso acrescentar outros, como Al-Kindi, De radiis. Mas há, também, textos de conteúdo teológico, por exemplo, as Regula caelestis iuris, de Alain de Lille, que usa o anônimo Liber viginti quattuor philosophorum (Livro dos vinte e quatro filósofos), particularmente sua primeira e segunda definiçóes de Deus. Na primeira, "Deus est monas monadem gignens in se unum reflectens ardorem" (Deus é o monas (uno) que gera uma unidade, um uno (monas), refletindo em si mesmo o único ardente éter). A segunda definição de Deus, "Deus est sphaera infinita cuius centrum est ubique, circumferentia nusquam" (Deus é a esfera infinita, cujo centro está por toda a parte e cuja circunferência, em lado nenhum), queria expressar "per modum imaginandi" (pelo modo da imaginação), ou seja, pelo modo de uma imagem ou de um rascunho, o que a primeira definição pretendia dar a pensar. A formulação paradoxal: Deus é a "esfera infinita, cujo centro está em toda parte e cuja periferia em lado nenhum" é ilustrada pela metáfora da luz: a luz infinita cria um raio infinito a brilhar, refletindo sobre si mesmo. "Infinito", porque o archetypus mundus é o "conteúdo" das ideias infinitas; "em toda parte", na reflexão (in reflexione) do criando sobre o criado e vice-versa. A periferia simboliza a sabedoria gerada (sapientia genita); "em lado nenhum" porque a luz é elevada, isto é, superior sobre todo o infinito, sobre todas as infinitas coisas, e é incluída em nada, ou seja, em nenhuma coisa; não "quantitatiue", mas segundo a "simplicidade de sua natureza" (sed simplicitate suae naturae). Assim, a infinita diversidade ou pluralidade do mundo inteligível, quer dizer, da "sphaera intelligibilis", é fundada numa simples unidade, ou seja, na simplicidade única do uno. $\mathrm{O}$ mundo é imago dei, uma imagem de Deus, como diz o Asclepius (Esculápio); ou com as palavras do Liber viginti quattuor philosophorum: "uniuersum est templum diuinum" (O universo é o templo divino). ${ }^{66}$ Talvez essa tese seja o

${ }^{65}$ Cf. LINDBERG, David C. Auge und Licht im Mittelalter. Die Entwicklung der Optik von Alkindi bis Kepler, übers. v. M. Althoff. Frankfurt a. M.: 1987 (Orig.: Theories of Vision from Al-Kindi to Kepler, Chicago, 1976); idem, Roger Bacon and the origins of perspective in the West. In: GRANT, E.; MURDOCH, J. E. (Ed.). Mathematics and its applications to science and natural philosophy in the Middle Ages. Essays in honor of Marshall Clagett. Cambridge, 1987, p. 249-268; idem, Roger Bacon on Light, Vision, and the Universal Emanation of Force. In: HACKETT, J. (Ed.), Roger Bacon and the Sciences. Commemorative Essays. Leiden/New York/Köln, 1997, p. 243-275.

${ }^{66}$ Cf. ALANUS DE INSULIS. Magister Alanus de Insulis Regulae caelestis iuris. In: HÄRING, N. M. (ed.). Archives d'Histoire Doctrinale et Littéraire du Moyen Âge 48,1981, p. 97-226; LILLE, A. V. Regulae theologiae. Regeln der Theologie. Lateinisch - deutsch, übersetzt und eingeleitet von Andreas Niederberger und Miriam Pahlsmeier. Herders Bibliothek der Philosophie des Mittelalters, hrsg. v. Matthias Lutz- 
centro da intelectualidade cristã e suas reflexóes da cosmologia, astronomia, metafísica e teologia.

Para concluir, em relação ao primeiro ponto exposto acima gostaria de prestar atenção à divisão das ciências naturais enquanto ciências reais da qual a cosmologia faz parte, tanto quanto a metafísica, que não se ocupa de uma realidade fingida, mas, assim como a cosmologia, também de uma realidade real e verdadeira (trans physicam) e seus princípios motrizes. Conhecemos uma "lei natural" da Antiguidade e da Idade Média, ou seja, uma definição comum do movimento provindo de Aristóteles: omne quod movetur ab alio movetur. Contudo, isso náo pode ir ao infinito; logo, deve haver um primeiro movendo, que não é movido por outro movido; que, então, só pode ser uma inteligência, pois é um automovimento, o qual é símbolo de uma inteligência. Por causa disso, a divisão da realidade entre uma realidade acima da esfera da lua e outra, embaixo dela. Essa definição aristotélica do movimento também acaba com Galilei e Descartes, para quem o movimento é um movimento contínuo até o repouso, ou seja, com I. Newton, um movimento para zero. ${ }^{67}$

$\mathrm{O}$ segundo ponto atinge a explicação da geração do mundo, caso o princípio ex uno non fit nisi unum seja um princípio verdadeiro. Na cosmologia, isso é um assunto da questão: quantos princípios motrizes precisamos assumir, para explicar os vários movimentos dos planetas? E. Brás explica essa questão, através da Cosmographia de Petrus Apianus, que arrolou quinze movimentos celestes não movidos. Aristóteles, se não me engano, cinquenta e três. A Idade Média conta com dez primeiros princípios motrizes: o primeiro é que se chama o céu cristalino (Dante Alighieri, Convívio II, xiv, 14) e que se chama também o firmamentum, o primum mobile e, em seguida, os movimentos dos planetas até o da lua.

A esse respeito, Avicena e o Liber de causis conhecem o seguinte modo da geração, isto é, criação do mundo: se o primeiro princípio, ou seja, o Uno é uma inteligência, um intelecto pensando sempre em ato, o que é que ele pensa? Se ele pensa sempre em ato, desse pensamento surge necessariamente

Bachmann, Alexander Fidora, Andreas Niederberger, Bd. 20. Freiburg, Basel, Wien: Herder, 2009, p. 56-64. Anônimo, Liber XXIV philosophorum. Das pseudohermenische Buch der vierundzwanzig Meister, In: BAEUMKER, C. Studien und Charakteristiken zur Geschichte der Philosophie insbesondere des Mittelalters. Gesammelte Vorträge und Aufsätze, ed. Martin Grabmann, Münster, Aschendorff, 1927, p. 194-214 (= Beiträge zur Geschichte der Philosophie des Mittelalters, v. XXV/2); Le livre des XXIV Philosophes, traduit du latin, édité et annoté par François Hudry, Grenoble, 1989.

${ }^{67}$ Def. III: Materie vis insita est potentia resistendi, qua corpus unumquodq; quantum in se est, perseverat in statu suo vel quiescendi vel movendi uniformiter in directum. (NEWTON, 1686, p. 8). 
uma segunda intelligentia; e se essa intelligentia pensa em sua origem enquanto uma possível intelligentia, surge daí o primeiro corpo celeste, o primum mobile e, assim, até a última intelligentia: a esfera da lua, onde é situado o intellectus agens ,que é cheio das formas inteligíveis e, a partir dele, efluem as espécies inteligíveis na alma intelectiva do homem, a saber, pelo qual o intellectus possibilis (intelecto possível), que é nosso intelecto, passa da potência ao ato de conhecer algo como tal coisa.

Também essa teoria de Avicena dos intelectos separados provindos de um conjunto da especulação metafísica, da cosmologia e do conhecimento não é aceitável para Tomás de Aquino (veja Suma de Teologia I, 79). A diferença entre intellectus agens e intellectus possibilis que Aristóteles faz, no III. Livro cap. 5 do De anima, Tomás interpreta de seguinte forma: a comparaçáo aristotélica do sol enquanto princípio das coisas coloridas com o intelecto agente enquanto princípio das coisas conhecidas, Tomás reúne junto com Agostinho (Confissóes X, 8: "Palácio da memória"), na metáfora da "luz intelectual", isto é, da "luz natural da razão" (GUILLET, 1927, p. 79-88), uma das metáforas mais importantes na história da filosofia. A "luz intelectual" representa o intelecto agente em nós.

O terceiro e quarto pontos do meu comentário posso juntar. Acerca de uma hierarquia dos corpos celestes, deveria ser de grande interesse o tratado De coelesti hierarchia de ps.-Dionysius Areopagita, que trata sobre a hierarquia dos intelectos separados que Tomás chama, com Dionysio, de anjos e que são, na filosofia de Avicena, as inteligências. O quarto ponto é um acréscimo, pois, a meu ver, essa metafísica da luz, ou seja, a ciência da perspectiva, explica bem a importância da cosmologia para uma teoria medieval do conhecimento, para uma concepção metafísica e teológica de toda a realidade, nas condiçôes do ser humano na vida presente.

A essa concepção pertence também o que se chama cosmographia, a questão da medida da terra através da interpretação dos sinais do céu e das constelaçóes dos astros e do sol e da lua, por exemplo para a previsão do tempo ${ }^{68}$ muito importante para o sobreviver do ser humano, por exemplo na agricultura, na medida do tempo das estaçóes do ano, ${ }^{69}$ nas orientaçóes nas

\footnotetext{
${ }^{68}$ BOS, Gerrit; BURNET, Charles (orgs.). Scientific Weather Forcasting in the Middle Ages: The Writings of Al-Kindi, Studies, Editions, and Translations of the Arabic, Hebrew, and Latin Texts, New York, Routledge, 2000, 2016.

${ }^{69}$ Cf. por exemplo: STERN, Sacha; BURNETT, Charles (orgs.). Time, Astronomy, and Calendars in the Jewish Tradition. Leiden ; Boston: E. J. Brill, 2014.
} 
viagens nas ruas e, sobretudo, na navegação no alto mar, por exemplo na época da descoberta da América no século XVI como a Cosmographiae Introductio de Martin Waldseemüller no ano de 1507 mostra. ${ }^{70}$ Cosmografia então tem a ver com uma construção de uma mappa mundi, daquela a Peutingeriana deve ser a primeira, a mapa no Império Romano, depois a mapa da terra de Erbstorf (1236) na Idade Média, a famosa Ymago mundi de Pierre d'Ailly, e depois outras até os globos modernos da nossa terra.

Assim, o IV. Livro da Meteora de Aristóteles é intitulado De impressionibus superioribus, por exemplo: Tractatus Petri de Eliaco ${ }^{71}$ Episcopi Cameracensis, Super libros Metheororum: de impressionibus aeris. Ac de hiis quae in prima, secunda, atque tertia regionibus aeris fiunt, sicut sunt Sydera cadentia, Stellae Cometae, Pluuia, Ros, Pruina, Nix, Grando, Ventus, Terraemotus, deque generatis infra terram. Conhecemos a influência da lua sobre a altura dos mares. ${ }^{72}$ Gostaria de sublinhar a importância prática da cosmologia para a nossa vida cotidiana. Então, temos a tomar em consideração vários termos para o mesmo fenómeno: 'astronomia', 'cosmologia', 'cosmografia' e 'astrologia' que têm vários sentidos em vários contextos.

Agradeço ao autor, E. Brás, por um artigo estimulante, que provocou minhas observaçóes e meu comentário.

\section{REFERÊNCIAS}

ARISTÓTELES. Metafisica. Tradução de Edson Bini. São Paulo: Edipro, 2014.

DAVIDSON, H. A. Alfarabi, Avicenna, \& Averroes, on Intellect. Their Cosmologies, Theories of the Active Intellect, and Theories of Human Intellect. Oxford: University Press, 1992.

GILSON, É. Pourquoi saint Thomas a critiqué saint Augustin? In: GILSON, É. Archives d'Histoire Doctrinale et Littéraire du Moyen Âge. Paris: J. Vrin, 1926. p. 5-127. t. I

GROSSETESTE, R. Tratado da luz e outros opísculos sobre a cor e a luz. Latim Português. Porto: Afrontamento, 2012.

${ }_{70}$ WALDSEEMÜLLER, Martin. Cosmographiae Introductio. New York: The United States Catholic Historical Society, 1907.

${ }^{71}$ Petrus de Alliaco, ou seja, Peter of Ailly ou Pierre d'Ailly (1350-1420): ymago mundi, e/ou a mappa mundi.

${ }^{72}$ Cf. por exemplo: MA'SAR, Abu. The Great Introduction to Astrology. Leiden; Boston, E. J. Brill, 2019, p. 262: "On the indication proper to the Moon for the ebb and flow". 
GUILLET, J. O.P., La "lumière intellectuelle" d'après S. Thomas. "oĩov to $\varphi \tilde{\omega} \varsigma$ " - De anima III, 5.430 a 15. In: Archives d'Histoire Doctrinale et Littéraire du Moyen Âge. Paris: J. Vrin, 1927. p. 79-88. t. II.

LITT, T. Les corps célestes dans l'univers de saint Thomas d'Aquin. Louvain: Publications Universitaires; Paris: Béatrice Nauwelaerts, 1963 (Philosophes Médiévaux, 7).

NEWTON, I. Philosophiae Naturalis Principia Mathematica, Julii 5. 1686, Londini Jussu Societatis Regiæ ac Typis Josephi Streater. Prostat apud plures Bibliopolas. Anno MDCLXXXVII, p. 8.

SAVONAROLA, G. De doctrina Platonicorum. In: Inter omnes Plato et Aristoteles: Gli Appunti Filosofici di Girolamo Savonarola, Introduzione, edizione critica e commento, Fédération Internationale des Instituts d'Études Médiévales, Textes et Études du Moyen Âge, 66, A cura di Lorenza Tromboni. Porto: Fédération Internationale des Instituts d'Études Médiévales, 2012. p. 239-262.

SCHNEIDER, J. H. J. The Eternity of the World. Thomas Aquinas and Boethius of Dacia. In: Archives d'Histoire Doctrinale et Littéraire du Moyen Âge. Paris: J. Vrin, 1999. p. 121-141. t. 66.

SCHNEIDER, J. H. J. Philosophy and Theology in the Islamic Culture: Al-Farabi's. De scientiis. Philosophy Study, Netherlands, v. 1, n. 1, p. 41-51, 2011.

SCHEINDER, J. H. J. A Imagem de Platão em Tomás de Aquino. Observaçóes a uma Controvérsia Medieval: Platão e/ou Aristóteles. Cultura e Fé Revista de Humanidades, Porto Alegre, ano 36, n. 143, p. 395-410, out./dez. 2013.

SCHNEIDER, J. H. J. A Teoria do Intelecto segundo Al-Farabi. Teologia e Filosofia no Mundo Árabe Latino Medieval. Poliética (PUC), São Paulo, v. 3 n. 2, p. 224-246, 2015. 
SCHNEIDER, J. H. J. 